\title{
COST ANALYSIS AND ECOLOGICAL BENEFITS OF ENVIRONMENTAL RECOVERY METHODOLOGIES IN BAUXITE MINING
}

\author{
João Carlos Costa Guimarães ${ }^{1}$, Dalmo Arantes de Barros ${ }^{1}$, José Aldo Alves Pereira ${ }^{2}$, Rossi Allan Silva ${ }^{1}$, \\ Antonio Donizette de Oliveira ${ }^{3}$, Luís Antônio Coimbra Borges ${ }^{4}$
}

(received: March 4, 2011; accepted: September 28, 2012)

\begin{abstract}
This work analyzed and compared three methods of environmental recovery in bauxite mining commonly used in Poços de Caldas Plateau, MG, by means of recovery costs and ecological benefits. Earnings and costs data of environmental recovery activities were obtained for the areas that belonged to the Companhia Geral de Minas - CGM, on properties sited in the city of Poços de Caldas, MG. The amount of costs of these activities was used to compare the recovery methods by updating them monetarily to a reference date, in other words, the present moment. It is concluded that the difference between the present value of costs for simple restoration and rehabilitation activities are less than $1 \%$ and that between the complete restoration and rehabilitation is about $15.12 \%$, suggesting that the choice of the methods to be used must be based on the ecological earnings proportional to each of them. The methodology of environmental restoration of the mining areas emphasizes the ecological variables in the process of establishment of the community, to the detriment of complex ecological aspects, which show difficulties in measuring the actual moment of the development of the ecosystem considered.
\end{abstract}

Key words: Mining, cost analysis, environmental restoration, environmental rehabilitation.

\section{ANÁLISE DOS CUSTOS E BENEFÍ́CIOS ECOLÓGICOS DE METODOLOGIAS DE RECUPERAÇÃO AMBIENTAL EM MINAS DE BAUXITA}

RESUMO: Neste trabalho, objetivou-se analisar e comparar três métodos de recuperação ambiental de áreas mineradas de bauxita comumente utilizadas na região do Planalto de Poços de Caldas, MG, por meio dos custos de recuperação e dos benefícios ecológicos. Obtiveram-se dados de rendimentos e custos das atividades de recuperação ambiental em áreas pertencentes à Companhia Geral de Minas - CGM, em propriedades localizadas no município de Poços de Caldas, MG. Para comparar os métodos de recuperação, utilizaram-se os valores dos custos dessas atividades, atualizando-os monetariamente para uma data de referência, ou seja, o momento atual. Concluiu-se que a diferença entre os valores atuais dos custos das atividades da restauração simples e reabilitação é menor do que $1 \%$ e entre restauração completa e reabilitação é cerca de $15,12 \%$, sugerindo que a escolha do método a ser usado deve se basear nos ganhos ecológicos proporcionados por cada um deles. A metodologia de restauração ambiental de áreas mineradas enfatiza as variáveis ecológicas no processo de estabelecimento da comunidade, enquanto a reabilitação fundamenta-se na cobertura do solo em curto prazo, em detrimento dos aspectos ecológicos complexos, os quais apresentam dificuldades de mensuração no momento atual de desenvolvimento do ecossistema avaliado.

Palavras-chave: Mineração, análise de custo, restauração ambiental, reabilitação ambiental.

\section{INTRODUCTION}

Mining activities as well as transformation to finished products corresponds to about $5 \%$ of the Gross Domestic Product (GDP). The balance of trade data published in 2007 featured that non-ferrous mining activity contributed $21 \%$ of the total exports, $13 \%$ of imports and $43 \%$ of Brazil's trade balance (LOBÃO, 2010).
Brazilian mining is under national and international pressure to protect the environment mainly by the rules of the International Organization for Standardization (ISO). This means that mining companies have to take on commitments and investments bigger than those being currently carried out to meet political and market demands (GRIFFITH et al., 1996 apud MOREIRA, 2004).

${ }^{1}$ Forest Engineer, Doctoral student of Forest Engineering - Universidade Federal de Lavras/UFLA - Departamento de Ciências Florestais - Cx. P. 3037 - 37200-000 - Lavras, MG, Brazil - joao.guimaraes77@gmail.com, dalmo.barros@uol.com.br, rossiallan@gmail.com ${ }^{2}$ Forest Engineer, Professor D.Sc. in Ecology - Universidade Federal de Lavras/UFLA - Departamento de Ciências Florestais - Cx. P. 3037 - 37200-000 - Lavras, MG, Brazil -j.aldo@dcf.ufla.br

${ }^{3}$ Forest Engineer, Professor D.Sc. in Forest Science - Universidade Federal de Lavras/UFLA - Departamento de Ciências Florestais - Cx. P. 3037 - 37200-000 - Lavras, MG, Brazil -donizete@dcf.ufla.br

${ }^{4}$ Forest Engineer, Professor D.Sc. in Forest Engineering - Universidade Federal de Lavras/UFLA - Departamento de Ciências Florestais Cx. P. 3037 - 37200-000 - Lavras, MG, Brazil - luis.borges@dcf.ufla.br 
Mining abandonment frequently entails serious socio-environmental problems to the communities around the enterprises. However, law asserts that all mined areas must be recuperated in order to lighten the environmental impacts of mining activities, even though they are not considered economic and have social impacts in the regions in which the mining activities were originally carried out. Agents and involved parties through the provision of financial resources and the presentation of guarantees must assert closing of mines by including the implementation costs and the management of the closure plan in the financial plan of the mining company. These costs will not be transferred to government agencies or to the community on the exhaustion of mineral reserves due to mining, or in the case of a quick interruption in mining caused by the bankruptcy of the mining company (LIMA et al., 2006).

Mining in tropical forests can cause fragmentation of ecosystems resulting in a series of threats to the local and regional biodiversity conservation (INSTITUTO DE PESQUISAS E ESTUDOS FLORESTAIS - IPEF, 2001). The recovery of these areas can provide a positive impact on soil fertility and on the biodiversity (ORLANDO et al., 2003; PFAFF et al., 2007), when the native species compatible to the local ecosystem are used in the rejuvenation process (COELHO, 2007).

Poços de Caldas Plateau is sited inside the Mata Atlântica or Atlantic Forest biome, where the remaining forest has significant environmental importance (MYERS et al., 2000). The Atlantic Forest regularizes the water supply, asserts the soil fertility, controls the regional climate and the local microclimate, and protects scarps and hillside of mountain ridges from erosion and collapse (RODRIGUES; GANDOLFI, 2000).

Atlantic Forest is classified to have five main types. Researches to develop technologies that aim at the restoration of this biome are underway. The objective of the restoration process is reconstituting new ecosystems close to the original by creating conditions to renew biodiversity, where the species have the conditions to be auto sustainable and the reproduction and genetic diversity in their population is warranted (ENGEL; PARROTA, 2003; KAGEYAMA; GANDARA, 2003).

The feasibility study for the recovery of degraded areas must be started before the mining exploration, according to Instituto Brasileiro do Meio Ambiente e dos Recursos Naturais Renováveis - IBAMA (1990), at the planning stage to derive advantages, including economic.
The soil removed for mining causes the loss of a big amount of organic material, reducing its fertility, and this can have a negative impact on the recovery of the degraded areas. Most of the time, soils in degraded areas show low levels of nutrients and physiochemical characteristics that are different from the original one.

Vegetation on the bauxite mined areas by Companhia Geral de Minas - CGM uses rehabilitation and restoration methods. The difference between methodologies for restoration and complete restoration, emphasizing on costs and ecological advantages, are shown in the following sections.

Recovery costs of the mined areas can be reduced by the selection of resistant plants that can grow with low availability of nutrients or those that are colonized by symbiotic microorganisms on the rhizosphere (OLIVEIRA et al., 2010). The initial success of recovery of a degraded ecosystem depends partly on the handling practices at the sites and on the species of the regional flora used for the reestablishment of the ecological process (MOREIRA, 2004).

However, faced with the diversity of the characteristics between the Brazilian biomes, and even inside each biome, it is not appropriate to use the same recovery method in all the regions as the conditions found in each environment can determine the procedures required for them and their respective costs (DEPRÁ et al., 2009). According to Carpanezzi (2005) and Rodrigues and Gandolfi (2000), the best strategy to restore and accelerate the recovery process is to smoothly enable the ecological succession system.

The distinction between the recovery process and restoration is based on details of the basic ecology, thus, the concern about interactive processes between plants and animals becomes very significant (REIS et al., 2003). According to Mariot et al. (2008), the importance of this distinction is strengthened by the National System of Conservation Units (Sistema Nacional de Unidade de Conservação - SNUC), Lei n ${ }^{\circ}$ 9.985/00 (BRASIL, 2000). According to this law, recovery means the recovery of an ecosystem or restitution of a sylvan population from a degraded condition to a non-degraded condition that can be different from the original condition. Restoration is defined as a restitution process of an ecosystem or a sylvan population to a condition as close as possible to the original.

Nucleation is a technique used to recover anthropogenic activities that contribute to the restoration of communities (REIS et al., 2003). Using the fundamental

Cerne, Lavras, v. 19, n. 1, p. 9-17, jan./mar. 2013 
principle of nucleation on restoration, the natural succession process is made effective by the use of numerous and diversified nucleuses. The principle of nucleation includes basic factors for the promotion of succession like increase in energy demand and biodiversity on the degraded environment. Reis et al. (2007) state that the application of the nucleation principle, based on the creation of diversity of nucleuses allows the local heterogeneity to express itself in areas to be restored by fostering the formation of distinct successional branches over time and space. This context propitiates higher environmental resilience and, consequently, higher local stability.

Restoration techniques through nucleation enable the reduction of implantation costs, besides enabling significant improvements on environmental qualities facilitating an increase in the occupation probability of this environment by other species. The techniques of nucleators include soil transposition, direct tillage and hydro-seeding, man-made perches, transposition of branches, planting seedlings in high diversity islands and gathering seeds to support genetic variability.

This work analyzed and compared three environmental recovery methods in bauxite mining areas rehabilitation, simple restoration and complete restoration through the valuation of the recovery costs and ecological benefits.

\section{MATERIAL AND METHODS}

Poços de Caldas Plateau, sited on the western edge of the Serra da Mantiqueira, in contact with the eastern extremes of Paraná Sedimentary Basin, forms a morphostructural set that is uniquely characterized by encompassing part of the Minas Gerais and São Paulo regions and shaped like a boiler because of extinct volcanic activities. Its position is determined by latitudes 21 and $22^{\circ} \mathrm{S}$ and by longitudes 46 and $47^{\circ} \mathrm{W}$, covering an area of about $800 \mathrm{~km}^{2}$.

The climate of the region is mesothermal type $C w b$. During the dry period the average temperature is $15^{\circ} \mathrm{C}$, with the minimum at $-6{ }^{\circ} \mathrm{C}$ and during the rainy season, the average temperature is $21{ }^{\circ} \mathrm{C}$. As per the data by the Meteorology and Water Resources System of Minas Gerais (Sistema de Metereologia e Recursos Hídricos de Minas Gerais -SIMGE) the annual precipitation is 1,300 to 1,600 $\mathrm{mm}$, rainfall for the rainy season (October to March) is 1,300 $\mathrm{mm}$ and for the dry period (April to September) is $300 \mathrm{~mm}$.

The study is based on the CGM natural deposit of ores, in the fields sited in Poços de Caldas city, Minas Gerais.

\subsection{Revegetation of mining areas}

\subsubsection{Rehabilitation (RB)}

This process has been practiced since 1978-1979 and, nowadays, it is used only in areas where the land before mining was used commercially (silviculture, pasture, agricultural growth etc.) in nature. The great strength of this process focuses on the quick elimination of visual impact and on the control of erosion process.

On mining exploration areas sited in areas previously covered by native forest it is common to use rehabilitation as the revegetation practice, and this can be divided into two stages: IMPLANTATION and MAINTENANCE.

The IMPLANTATION stage is constituted by the following actions: liming the land to reduce soil acidity, chemical and organic fertilization in the pit, planting native and exotic species (without distinction) at a density of 1600 seedlings per hectare. Species are selected based on fast initial growth, wherein the seedlings are ordered in lines and a cocktail of exotic grass species (green carpet) that grows quickly is sowed between the rows of the planted lines.

The MAINTENANCE stage is executed for three years subsequent to the implantation, termed "coroamento" (weed control and retention of water with $1.4 \mathrm{~m}$ diameter) of seedlings and by the addition of fertilizer topdressing. It should be noted that due to the low density of the seedlings planted in the soil in the implantation stage and the high competitive power of the grass that forms the green carpet, it is common to do replanting of the dead seedlings in the first year of maintenance, totaling about $10 \%$.

\subsubsection{Restoration}

Restoration is the most recent process, chosen by the CGM in the Poços de Caldas since the agricultural year 2005-2006. It is used on areas where, before mining, the soil is covered by the native forest vegetation. The company uses two restoration methods, which are described below.

\subsubsection{Simple Restoration (RTS)}

Similar to rehabilitation, simple restoration is subdivided into implantation and maintenance, which lasts for three years. Implantation is composed of the following actions: restricted planting of native species at an average density of 4200 seedlings per hectare, misalignment spread, giving an aspect that is more close to the natural and chemical fertilization in the pit.

Cerne, Lavras, v. 19, n. 1, p. 9-17, jan./mar. 2013 
Maintenance stage is simpler than that applied during rehabilitation, because there is no sowing of exotic grass and coroamento of seedlings is unnecessary, and, therefore only the addition of fertilizer topdressing is done. Control of exotic grass invaders (Brachiaria decumbense and Melinis minutiflora) is performed just in isolated points where eventually these individuals are in abundance, in order to inhibit their expansion.

\subsubsection{Complete Restoration (RTC)}

Complete Restoration - RTC is a refinement of RTS, where some activities are added at those adopted in RTS. At situations where an area is under the initial process of restoration and there is an adjacent area of forest that will be suppressed for mining, a rescue of seedlings is done, enabling creation of seedlings of species that are difficult to find, broadening the diversity of the native species and reducing impacts on biodiversity. Besides, the forest litter is removed, which is immediately spread to the restoration area, increasing the potential of natural regeneration of the native species.

Another practice is the installation of man-made perches, which is used to create points of landing for native birds, improving the connectivity between the degraded area and fragments around and expanding the supply potential of seeds of native species.

\subsection{Comparing methods of revegetation}

To compare the methods of restoration and rehabilitation in the mined areas, their activity costs discounted to the same reference date, were used as base values and considered the present moment. The interest rate used to discount the costs was $6 \%$ per year. The present value for each item was obtained applying the equation to discount monetary values on the regime of compound interest that, according to Rezende and Oliveira (2008) is given by:

$V_{0}=\frac{V_{m}}{(1+i)^{m}}$

where:

$\mathrm{V}_{\mathrm{o}}=$ Present value of cost;

$\mathrm{V}_{\mathrm{m}}=$ Final value (when that happens) of cost;

$\mathrm{m}=$ Year of occurrence of cost;

$\mathrm{i}=$ Annual interest rate.

Costs of recovery activities related to the three methods studied were obtained using a historical demand for labor and inputs to each other as base values paid by CGM or that it would have to pay.

The "ecological benefits" were structured on a matrix, featuring management activities, classified into four classes: inputs, planting maintenance, forest structure and biodiversity; apart from methodological definition and biodiversity. Data analysis was done to include positive management activities and aspects that provide ecological benefits, and were biased toward the return of the typical biodiversity of the original ecosystem and, consequently, facilitating the environmental sustainability characteristics of native tropical forests.

Finally, ecological benefits provided by the three methods were analyzed together with the costs to discuss and conclude what methodology is more feasible and, therefore must be prioritized.

\section{RESULTS AND DISCUSSION}

\subsection{Cost analysis}

Table 1 shows costs related to the complete restoration activities (method 1 ) and the simple restoration (method 2). Regardless of the method, the most significant cost is that of planting labor. In method 1 the implantation cost is greater than that in method 2 due to the occurrence of labor cost to remove and spread the forest litter and installing perches.

Costs of activities of rehabilitation are shown in Table 2. For the implantation activities, labor costs for planting are the most significant, therefore on a smaller scale that occurs for the restoration method.

To compare the costs of the annual implantation and maintenance activities of the three methods of environmental recovery, the present value of costs, as shown in Table 3 was determined. The environmental recovery by the complete restoration method has a total present value greater than that of the rehabilitation method. On the other hand, for environmental recovery through the restoration, if the withdrawal and the scattering of litter or installation of perches is not done, the total present value of restoration costs will be lower than that of rehabilitation.

Regardless of the method, the cost of implantation activities is the most significant. In complete restoration, implantation costs account for $85.5 \%$ of the total, and the rehabilitation of such participation is only $60.2 \%$. The adoption of a higher seedling planting density in the methods for restoration in relation to rehabilitation raises the labor costs for planting, explaining in part the difference in the implantation costs. 
Table 1 - Costs per hectare of restoration activities in bauxite mining areas for the two methods studied.

Tabela 1 - Custos por hectare das atividades para restauração de áreas mineradas de bauxita para os dois métodos estudados.

\begin{tabular}{|c|c|c|c|c|c|c|}
\hline \multirow{2}{*}{ Breakdown of activities } & \multirow{2}{*}{$\begin{array}{c}\text { Year of } \\
\text { occurrence }\end{array}$} & \multirow{2}{*}{ Unit } & \multirow{2}{*}{$\begin{array}{c}\text { Cost } \\
\text { (R\$/unity) }\end{array}$} & \multirow{2}{*}{ Quantity } & \multicolumn{2}{|c|}{ Cost $(\mathrm{R} \$ / \mathrm{ha})$} \\
\hline & & & & & Method $1^{*}$ & Method $2^{*}$ \\
\hline \multicolumn{7}{|l|}{ Implantation } \\
\hline Labor for planting (pit of $20 \times 20 \times 20 \mathrm{~cm}$ ) & 0 & seedling & 3.42 & 4,200 & $14,364.00$ & $14,364.00$ \\
\hline Labor for removal and scattering of litter & 0 & ha & $3,400.00$ & 1 & $3,400.00$ & - \\
\hline Labor for installation of perches & 0 & perch & 30.00 & 10 & 300.00 & - \\
\hline Seedlings & 0 & seedling & 1.00 & 4,200 & $4,200.00$ & $4,200.00$ \\
\hline Fertilizer Fertium Phos HF (0.4 Kg/pit) & 0 & tonne & 828.00 & 1.68 & $1,391.04$ & $1,391.04$ \\
\hline Total Implantation & & & & & $23,655.04$ & $19,955.04$ \\
\hline \multicolumn{7}{|l|}{ Annual Maintenance } \\
\hline $\begin{array}{l}\text { Labor for topdressing, control of Brachiaria } \\
\text { decumbense, Melinis minutiflora and lianas }\end{array}$ & 1,2 e 3 & ha & $1,000.00$ & 1 & $1,000.00$ & $1,000.00$ \\
\hline NPK $20-00-20$ topdressing $(0.1 \mathrm{~kg} / \mathrm{pit})$ & 1,2 e 3 & $\mathrm{~kg}$ & 0.92 & 420 & 386.40 & 386.40 \\
\hline Fertium topdressing $(0.1 \mathrm{Kg} /$ cova $)$ & 1,2 e 3 & tonne & 267.00 & 0.42 & 112.14 & 112.14 \\
\hline Total Annual Maintenance & & & & & $1,498.54$ & $1,498.54$ \\
\hline
\end{tabular}

* Method 1 is complete restoration (RTC) and method 2 is simple restoration (RTS)

Table 2 - Costs per hectare of rehabilitation activities in bauxite mining areas.

Tabela 2 - Custos por hectare das atividades para reabilitação de áreas mineradas de bauxita.

\begin{tabular}{|c|c|c|c|c|c|}
\hline Breakdown of activities & $\begin{array}{c}\text { Year of } \\
\text { occurrence }\end{array}$ & Unit & $\begin{array}{c}\text { Cost } \\
\text { (R\$/unity) }\end{array}$ & Quantity & Cost $(\mathrm{R} \$ / \mathrm{ha})$ \\
\hline \multicolumn{6}{|l|}{ Implantation } \\
\hline Labor for planting (pit of $40 \times 40 \times 40 \mathrm{~cm}$ ) & 0 & seedling & 4.00 & 1,600 & $6,400.00$ \\
\hline NPK 04-14-08 (0.25 Kg/pit) & 0 & $\mathrm{~kg}$ & 0.70 & 400 & 280.00 \\
\hline Organic compound (20 liters/pit) & 0 & liter & 0.075 & 32,000 & $2,400.00$ \\
\hline Limestone (3 tonne/ha) & 0 & tonne & 123.33 & 3 & 370.00 \\
\hline Labor for liming & 0 & ha & 350.00 & 1 & 350.00 \\
\hline Seedlings & 0 & seedling & 1.00 & 1,600 & $1,600.00$ \\
\hline Green carpet (cocktail of seeds) & 0 & $\mathrm{~kg}$ & 4.76 & 352.8 & $1,679.33$ \\
\hline Labor to sow the green carpet & 0 & ha & 1.00 & 1,400 & $1,400.00$ \\
\hline Total Implantation & & & & & $14,479.33$ \\
\hline \multicolumn{6}{|l|}{ Annual Maintenance } \\
\hline Labor (crowning and topdressing) & 1,2 e 3 & ha & $3,000.00$ & 1 & $3,000.00$ \\
\hline NPK 04-14-08 topdressing (0.25 kg/pit) & 1,2 e 3 & $\mathrm{~kg}$ & 0.70 & 400 & 280.00 \\
\hline $\begin{array}{l}\text { Replanting just on } 1^{\text {st }} \text { maintenance ( } 10 \% \\
\text { of mortality: seedlings, inputs, labor) }\end{array}$ & 1 & ha & 828.00 & 1 & 828.00 \\
\hline Total Annual Maintenance & & & & & $4,108.00$ \\
\hline
\end{tabular}


Table 3 - Present value for implantation and maintenance costs of the environmental recovery methods studied.

Tabela 3 - Valor Atual dos Custos $(R \$ / h a)$ de Implantação e Manutenção para os métodos de recuperação ambiental estudados.

\begin{tabular}{lcccrrr}
\hline & \multicolumn{5}{c}{ Environmental recovery method } \\
\cline { 2 - 7 } Phase & Rehabilitation & $\%$ & $\begin{array}{c}\text { Simple } \\
\text { restoration }\end{array}$ & $\%$ & $\begin{array}{c}\text { Complete } \\
\text { restoration }\end{array}$ & $\%$ \\
\hline Implantation (year 0) & $14,479.33$ & 60.26 & $19,955.04$ & 83.28 & $23,655.04$ & 85.52 \\
$1^{\text {st }}$ Maintenance (year 1) & $3,875.47$ & 16.13 & $1,413.72$ & 5.90 & $1,413.72$ & 5.11 \\
$2^{\text {nd }}$ Maintenance (year 2) & $2,919.19$ & 12.15 & $1,333.70$ & 5.57 & $1,333.70$ & 4.82 \\
$3^{\text {rd }}$ Maintenance (year 3) & $2,753.95$ & 11.46 & $1,258.20$ & 5.25 & $1,258.20$ & 4.55 \\
Total maintenance & $9,548.61$ & 39.74 & $4,005.62$ & 16.72 & $4,005.62$ & 14.48 \\
\hline Total present value & $24,027.94$ & 100.00 & $23,960.66$ & 100.00 & $27,660.66$ & 100.00 \\
\hline
\end{tabular}

The maintenance cost related to the rehabilitation method is $39.74 \%$ higher than that of the restoration methods (respectively, $16.72 \%$ and $14.48 \%$ for RTS and RTC), because that method takes a major effort to control species grasses to ensure that the growth and development of the seedlings are not affected and prevent their death. In the process of simple restoration, the maintenance is smaller since it consists of applying fertilizer topdressing and punctual control of exotic grasses, focusing only at points where invasion by Brachiaria decumbense and Melinis minutiflora seeds that originates from the surrounding areas.

The difference between maintenance costs for the rehabilitation method and for the restoration methods is more pronounced in the first year $(16.13 \%, 5.90 \%$ and $5.11 \%$ respectively, for RB, RTS and RTC), because the rehabilitation process advocates replanting of dead seedlings, which is not required for the other two methods.

\subsection{Ecological benefits}

As featured in Table 4, the analysis of the ecological benefits shows the gains arising from the methodological differences. Rehabilitation has the basic concept of a quick return of vegetation to the degraded site, so that the visual impact is eliminated. The application of concepts derived from agricultural and forest production is evidenced by the application, in both sectors, such as lime to reduce acidity in the ground, spacing and alignment of planting seedlings. In these, a restricted group of species is adopted, usually selected for achieving a good growth rate. In addition, to accelerate the recovery of the land, a cocktail of grasses and herbaceous species of rapid growth, both plants from the seed bank contained in the topsoil, as well as seeds from the surroundings, (called green carpet) is introduced, a process normally used in the formation and recovery of pastures, endangering the natural regeneration of the native species.

In contrast, premise for restoration is on the return of ecological relationships that are essential to the building and maintaining of a natural forest over time, and therefore adopts silviculture practices that seek to replicate the patterns of a patch of forest in the initial process of construction of natural succession. Aumond (2003) argued that environmental restoration currently leads a new integrated approach, taking into account the theory of complex dynamical systems, which are considered the principles of ecology, the laws of thermodynamics and its implications for the entropy of the ecosystems. Additionally, Carpanezzi (2005) noted that the resilience of an area is underestimated by individualized assessments of vegetation, while ecosystems are formed by many other components.

The litter used in the field in the process of RTC acts as a blanket for the entry of seeds and the incorporation of these to the soil seeds bank (RODRIGUES; GANDOLFI, 2010). On to this blanket (seed bank), the presence of viable seeds (HARPER, 1977), whose litter is directly related to the establishment of plant populations, the maintenance of species diversity, establishment of ecological groups and the restoration of species richness during forest regeneration after natural or anthropogenic disturbances is added (HARPER, 1977; ZHANG et al., 2001). According to Braga et al. (2008), Martins (2009a, 2009b) and Martins et al. (2008), this is been used as an ecological indicator of assessment and monitoring of the regeneration of ecosystems under restoration.

Cerne, Lavras, v. 19, n. 1, p. 9-17, jan./mar. 2013 
Table 4 - Aspects related to the methodological basis and biodiversity for rehabilitation and restoration of bauxite mining areas in Poços de Caldas Plateau, MG.

Tabela 4 - Aspectos relativos ao embasamento metodológico e à biodiversidade para reabilitação e restauração de áreas mineradas de bauxita no planalto de Poços de Caldas, $M G$.

\begin{tabular}{lcc}
\hline Methodological basis & Rehabilitation & Restoration \\
\hline Science base & Agronomy and forestry production & Ecology and biology \\
Mitigation of visual impact & Major & Minor \\
Erosion control & Major & Major \\
Mitigation of impacts to biodiversity & Not considered & Major \\
Ecological relationships & Not considered & Major \\
Natural succession & Not considered & Major \\
Interactions "plant x animal" & Not considered & Major \\
\hline Considerations related to biodiversity & Rehabilitation & Restoration \\
\hline Natural regeneration & Very low & High \\
Herbivores & Very low & High \\
Phenological diversity & Low & High \\
Litter formation & Low or null & Present (from $2^{\text {nd }}$ and $3^{\text {rd }}$ year) \\
Covering the entire field & Very fast (2 or 3 months) & Medium (between 12 and 18 months) \\
Plant density & Low & High \\
Basis for definition of plant density & Forest production & Dynamics of gap \\
Exotic species & High & Very low or null \\
\hline
\end{tabular}

Compared to the rehabilitation, restoration adopts a reduced planting space by increasing the number of seedlings planted to about 2.5 times to obtain an even more natural aspect, and suggests that the distribution of seedlings is done at irregular spacing. Additionally it the green carpet, which allows the germination of many native plants, and it thus widens the density of plants and the species diversity. Some obvious benefits are the restoration of the formation of litter in the second year after planting, diversity and overlapping of reproductive periods of species and the return of native fauna.

The final values for the implantation of RTC and RB obtained a $15.12 \%$ difference, possibly justifying the greater ecological commitment. Since RB and RTS values were very close ( $0.28 \%$ difference), they are nearly equal economically.

\section{CONCLUSIONS}

In the process of environmental recovery by using restoration methodologies, most of the costs focuses on activities related to implantation, while for the RB method, about $40 \%$ of costs are due to maintenance activities.

The difference between the present value of the RTS and $\mathrm{RB}$ activities is small, suggesting that the choice of the method to be used can be based on the environmental gains provided by each one. To choose the best method further evaluation regarding the ecological benefits is still needed. The RTC method shows higher cost and there is not enough information to compare it ecologically with the RB and RTS.

The methodology for environmental restoration of the mined areas emphasizes on the ecological variables in the process of establishment of the community, while for rehabilitation it is based on land cover in the short term at the expense of ecological aspects.

\section{REFERENCES}

AUMOND, J. J. Teoria dos sistemas: uma nova abordagem para a recuperação e restauração ambiental. In: SIMPÓSIO BRASILEIRO DE ENGENHARIA AMBIENTAL, 2., 2003, Itajaí. Anais... Itajaí: UNIVALI, 2003. p. 43-49.

BRAGA, A. J. T.; GRIFFITH, J. J.; PAIVA, H. N.; MEIRA NETO, J. A. A. Composição do banco de sementes de uma floresta semidecidual secundária considerando o seu potencial de uso para recuperação ambiental. Revista Árvore, Viçosa, v. 32, n. 6, p. 1089-1098, nov./dez. 2008.

Cerne, Lavras, v. 19, n. 1, p. 9-17, jan./mar. 2013 
BRASIL. Lei 9.985, de 18 de julho de 2000. Institui o Sistema Nacional de Unidades de Conservação da Natureza. Diário Oficial [da] República Federativa do Brasil, Brasília, 19 jul. 2000.

CARPANEZZI, A. A. Fundamentos para a reabilitação de ecossistemas florestais. In: GALVÃO, A. P. M. (Ed.).

Restauração florestal: fundamentos e estudos de caso. Colombo: EMBRAPA Florestas, 2005. p. 27-45.

COELHO, M. C. C. Restauração de mata ciliar pela viabilização de crédito de carbono: uma proposta sócioambiental para comunidade de baixa renda. 2007. 110 p. Dissertação (Mestrado em Pesquisas Energéticas e Nucleares) Universidade de São Paulo, 2007.

DEPRÁ, G. F.; GRANDI, D. H.; MATAVELLI, C. J.; FERREIRA, J. D.; LIMA, A. D. V. Estimativa de custos para recuperação da vegetação em áreas de preservação permanente e reserva legal no estado de Santa Catarina. In: CONGRESSO BRASILEIRO DE ENGENHARIA DE AVALIAÇÕES E PERÍCIAS, 15., 2009, São Paulo. Anais... São Paulo: IBAPE/ SP, 2009. 1 CD-ROM.

ENGEL, V. L.; PARROTA, J. A. Definição a restauração ecológica: tendências e perspectivas mundiais. In: KAGEYAMA, P. Y.; OLIVEIRA, R. E.; MORAES, L. F. D.; ENGEL, V. L.; GANDARA, F. B. Restauração ecológica de ecossistemas naturais. Botucatu: FEPAF, 2003. p. 2-26.

HARPER, J. L. Population biology of plants. London: Academic, 1977. 892 p.

INSTITUTO BRASILEIRO DO MEIO AMBIENTE E DOS RECURSOS NATURAIS RENOVÁVEIS. Manual de recuperação de áreas degradas pela mineração: técnicas de revegetação/IBAMA. Brasília, 1990. 96 p.

INSTITUTO DE PESQUISAS E ESTUDOS FLORESTAIS. Conservação dos recursos hídricos por meio da recuperação e da conservação da abertura florestal da bacia do Rio Corumbataí. Piracicaba, 2001. 301 p. Plano Diretor.

KAGEYAMA, P. Y.; GANDARA, F. B. Restauração e conservação de ecossistemas tropicais. In: CULLEN JÚNIOR, L.; VALLADARES-PÁDUA, C.; RUDRAN, R. (Ed.). Métodos de estudo em biologia da conservação \& manejo da vida silvestre. Curitiba: UFPR; Fundação O Boticário de Proteção à Natureza, 2003. p. 383-394.

LIMA, H. M. de; FLORES, J. C. do C.; COSTA, F. L. Plano de recuperação de áreas degradadas versus plano de fechamento de mina: um estudo comparativo. REM: Revista Escola de Minas, Ouro Preto, v. 59, n. 4, p. 397-402, 2006.

LOBÃO, E. Panorama e desafios do setor mineral brasileiro. Disponível em: 〈http://www.valoronline.com.br〉. Acesso em: 8 jul. 2010.

MARIOT, A.; MARTINS, L. C.; VIVIANI, R. G.; PEIXOTO, E. R. A utilização de técnicas nucleadoras na restauração ecológica do canteiro de obras da UHE Serra do Facão, Brasil. Florianópolis: ORB, 2008. 18 p.

MARTINS, S. V. Recuperação de áreas degradadas: ações em áreas de preservação permanente, voçorocas, taludes rodoviários e de mineração. Viçosa, MG: Aprenda Fácil, 2009a. 270 p.

MARTINS, S. V. Soil seed bank as indicator of forest regeneration potential in canopy gaps of a semideciduous forest in Southeastern Brazil. In: FOURNIER, M. V. (Ed.). Forest regeneration: ecology, management and economics. New York: New Science, 2009b. p. 113-128.

MARTINS, S. V.; ALMEIDA, D. P.; FERNANDES, L. V.; RIBEIRO, T. M. Banco de sementes como indicador de restauração de uma área degradada por mineração de caulim em Brás Pires, MG. Revista Árvore, Viçosa, v. 32, n. 6, p. 10811088, nov./dez. 2008.

MOREIRA, P. R. Manejo do solo e recomposição da vegetação com vistas à recuperação de áreas degradadas pela extração de bauxita, Poços de Caldas, MG. 2004. 139 p. Tese (Doutorado em Ciências Biológicas) - Universidade Estadual Paulista "Júlio de Mesquita Filho", Rio Claro, 2004.

MYERS, N.; MITTERMEIER, R. A.; MITTERMEIER, C. G.; FONSECA, G. A. B.; KENY, J. Biodiversity hotspots for conservation priorities. Nature, London, v. 403, p. 853-845, 2000.

OLIVEIRA, D. E. C.; SILVA, A. V.; ALMEIDA, A. F.; SAI, E. F; RAYMUNDO JÚNIOR, O. Fungos micorrízicos arbusculares e rizóbio no crescimento inicial de Acacia mangium Willd. em solo de mineração da região sudoeste do estado de Goiás. Global Science and Technology, Rio Verde, v. 3, n. 1, p. 1-10, 2010.

Cerne, Lavras, v. 19, n. 1, p. 9-17, jan./mar. 2013 
ORLANDO, B.; BALDOCK, D.; CANGER, S.; MACKENSEN, J.; MAGINNIS, S.; SOCORRO, M.; RIETBERGEN, S.; ROBLEDO, C. Y.; SCHNEIDER, N. Carbono, bosques y gentes: hacia el manejo integrado del secuestro del carbon, el medio ambiente y la subsistencia sostenible. Gland: UICN, 2003. 42 p.

PFAFF, A.; KERR, S.; LIPPERC, L.; CAVATASSIC, R.; DAVISC, B.; HENDYB, J.; SANCHEZ-AZOFEIFAD, G. A. Will buying tropical Forest carbon benefit?: evidence from Costa Rica. Land Use Policy, Guildford, v. 24, p. 600-610, 2007.

REIS, A.; BECCHARA, F. C.; ESPÍNDOLA, M. B.; VIEIRA, N. K.; SOUZA, L. L. Restauração de áreas degradadas: a nucleação como base para incrementar os processos sucessionais. Natureza \& Conservação, Curitiba, v. 1, n. 1, p. 28-36, 2003.
REIS, A.; TRES, D. R.; SCARIOT, E. C. Restauração na floresta ombrófila mista através da sucessão natural. Pesquisa Florestal Brasileira, Colombo, n. 55, p. 67-73, jul./dez. 2007.

REZENDE, J. L. P.; OLIVEIRA, A. D. Análise econômica e social de projetos florestais. 2. ed. Viçosa, MG: UFV, 2008. v. $1,386 \mathrm{p}$.

RODRIGUES, R. R.; GANDOLFI, S. Conceitos, tendências e ações para recuperação de Florestas Ciliares. In:

Matas ciliares: conservação e recuperação. São Paulo: FAPESP, 2000. p. 235-247.

ZHANG, Z. Q.; SHU, W. S.; LAN, C. Y.; WONG, M. H. Soil seed banks as an input of seed source in revegetation of lead/ zinc mine tailings. Restoration Ecology, Malden, v. 9, p. 378$385,2001$. 
